\title{
Technical Sheet of Valorization of Cashew Apple Juice (Anacardium Occidentale L.) By Association with Passion Fruit Juice (Paciflora Edulis)
}

\author{
Adou Marc ${ }^{1,2}$, Kouadio Kouadio Olivier ${ }^{1}$ and Kouadio Degbeu Claver ${ }^{1}$ \\ ${ }^{1}$ Laboratory of Food Biochemistry and Tropical Products Technology, University of Abobo-Adjamé, UFR/STA, \\ 02 BP 801 Abidjan 02, Cote d'Ivoire, adou_marc@yahoo.fr \\ ${ }^{2}$ National Laboratory of Public Health of Cote d'Ivoire, 18 BP 2403 Abidjan 18, Côte d'Ivoire
}

\begin{abstract}
The sensory analysis of blend juice from cashew apple juice (Anacardium Occidentale L.) and passion juice (Paciflora Edulis) was conducted. Of the three proportions of mixture $(v / v)$, the mixture C (90/10) seems best appreciated by the panelists. This study shows that cashew apple can be valued in juice with better acceptance if mixed with exotic fruit juices such as passion fruit.
\end{abstract}

Keywords: Cashew apple, juice, panelists, passion fruit, sensory analysis

\section{INTRODUCTION}

Several studies have been carried out on cashew apples in general, including physico-chemical characterization ([1], [2], [3]). More specifically, the apple of cashew nuts and apples of Côte d'Ivoire has also been the subject of several studies ([4], [5], [6]). However, the cashew apples of Cote d'Ivoire are not valued [7]. However, in the course of 2016, this country produced more than $625000 \mathrm{~T}$ of cashew nuts (Anacardium Occidentale L.) [8], whose proportion of apples is destroyed to the detriment of the nut. Despite the richness of the juice from the cashew apples and all the beneficial effects, the cashew apples juice rejected because of its astringency. To improve consumer acceptance, this study proposes to mix the cashew apples juice with that of Paciflora Edulis f. Flavicarpa known under the pseudonym of "passion fruits". Indeed, the fruit of the passion is a fruit with a very acid pulp, an intense aroma and a pleasant flavor [9]. Different proportions of mixtures of the two juices were therefore submitted to a panel for sensory analysis in order to improve consumers' perception of cashew apples juice.

\section{MATERIAL AND METHODS}

Cashew apples juice (Photo 1) and passion fruits (Photo 2) were extracted according to figures a and $b$. The different juices obtained (photographs 3 and 4) were stored in the refrigerator (Fiocchetti, Mazzara, Italy) at $4{ }^{\circ} \mathrm{C}$, for the various tests. The $\mathrm{pH}$ of the juice was determined using a $\mathrm{pH}$ meter by the method described by AOAC [10]. The titratable acidity of the juices was determined by the method described by Kimaryo et al. [11]. The soluble solids level (TSS or Brix degree) was determined by the Soyer et al. method [12]. The dry matter was determined by the method described by BIPEA [13]. The ash content of the juices was determined by the method of incineration at $550{ }^{\circ} \mathrm{C}$. The density of the different juices was determined by introducing a densimeter into the sample at a temperature of $20^{\circ} \mathrm{C}$. The different mixtures $(\mathrm{C}, \mathrm{E}$ and $\mathrm{D})$ of the fruit juices are given in Table 1 . The sensory analysis was carried out on the attributes such as color, odor, flavor, decantation of the juice and a more general acceptance according to the method described by Stone and Sidel [14] and applied more specifically to cashew juice by Talasila et al. [15]. A panel of 30 people was constituted for the analysis with a scale ranging from "extremely pleasant" (point 9) to "extremely unpleasant" (points 1).

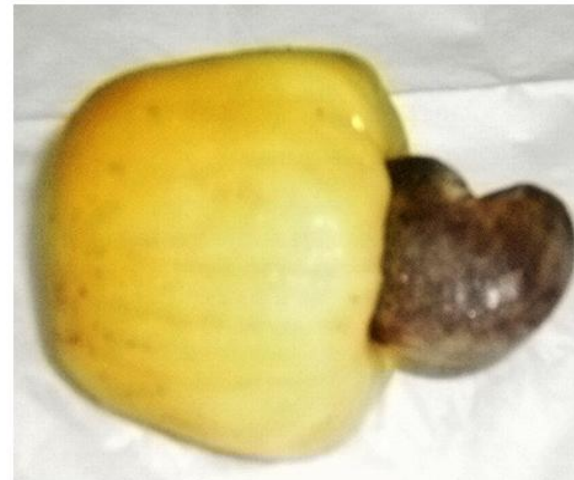

Photographie 1: Yellow cashew apples

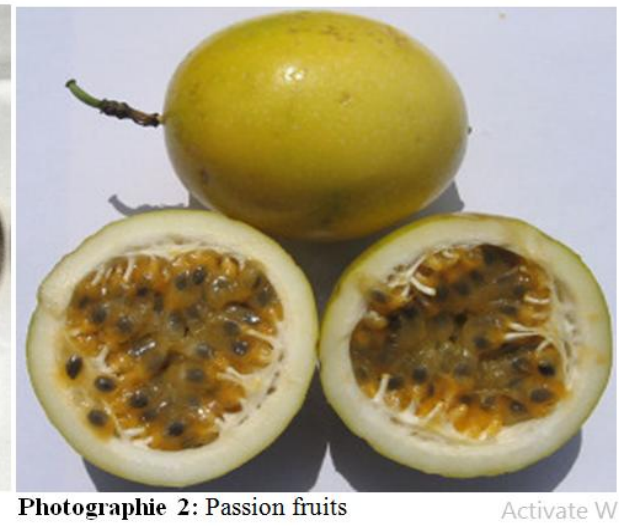




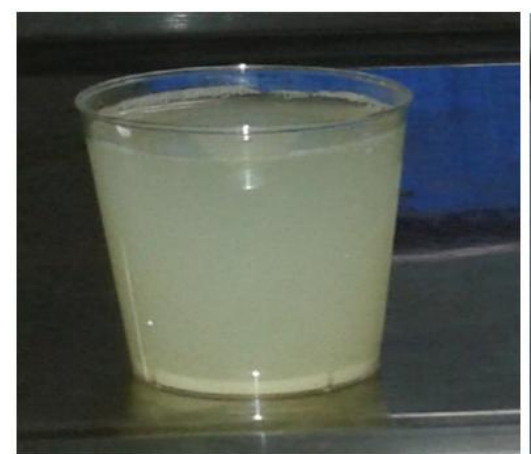

Photographie 3 : Cashew apples juice

Flowchart of juices
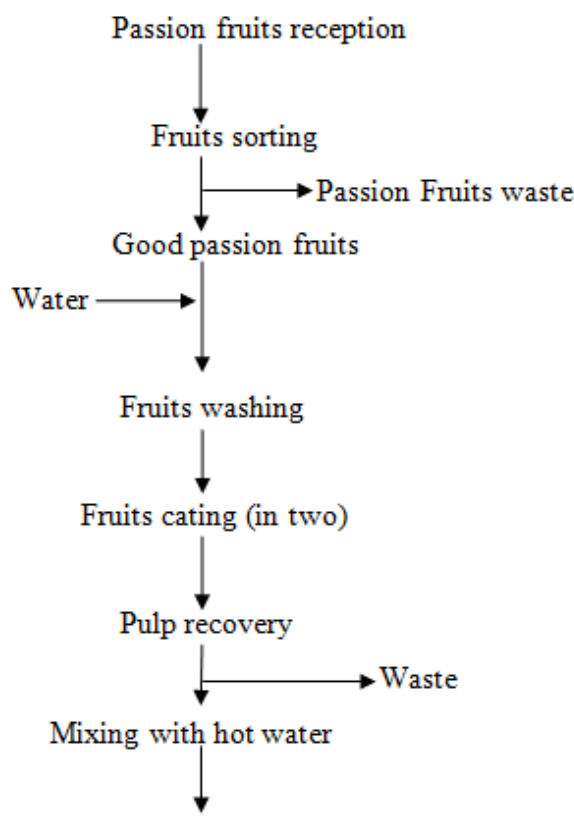

Filtration $(0,5 \mathrm{~mm}$ mesh screen)

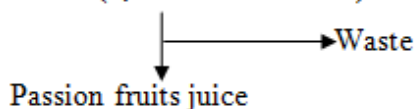

Passion fruits juice

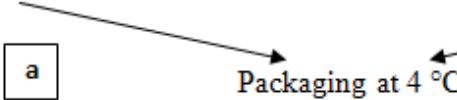

Figure 1: Flowcharts of juices production. a: Passion fruits, $\mathrm{b}:$ Cashew apples juice

Tableau 1: Blend of the cashew apples juice and passion fruits juice in different proportion

\begin{tabular}{|l|l|l|l|l|}
\hline $\mathrm{N}^{\circ}$ & Blend juice & Passion juice & Cashew apple juice & Total quantity \\
\hline 1 & A & $70 \mathrm{~mL}$ & $30 \mathrm{~mL}$ & $100 \mathrm{~mL}$ \\
\hline 2 & B & $80 \mathrm{~mL}$ & $20 \mathrm{~mL}$ & $100 \mathrm{~mL}$ \\
\hline 3 & C & $90 \mathrm{~mL}$ & $10 \mathrm{~mL}$ & $100 \mathrm{~mL}$ \\
\hline
\end{tabular}

\section{RESULTS AND DISCUSSION}

The physico-chemical characteristics of the two juices are summarized in Table 2. These characteristics show a similarity between these juices. This similarity seems to demonstrate a good ability of the two juices to mix.

Tableau 2: Physico-chemical composition of cashew apples juice and passion fruits juice

\section{Parameter}

Average (Cashew apple)

Average (passion fruit) 
Technical sheet of valorization of Cashew apple juice (Anacardium Occidentale L.) by association

\begin{tabular}{|l|l|l|}
\hline $\mathrm{pH}$ & $4,20 \pm 0,00$ & $3,14 \pm 0,02$ \\
\hline Titrable acidity (g lactic acid / $)$ & $0,79 \pm 0,00$ & $1,17 \pm 0,01$ \\
\hline Degré Brix $\left({ }^{\circ} \mathrm{B}\right)$ & $13,70 \pm 0,00$ & $14,17 \pm 0,01$ \\
\hline Indice of réfraction (RI) & $1,35 \pm 0,00$ & $1,34 \pm 0,00$ \\
\hline Density & $1,05 \pm 0,00$ & $1,60 \pm 0,00$ \\
\hline
\end{tabular}

Figure 2 gives the results of the comparison of the attributes of mixture A (mixture of cashew apple juice and passion juice 30-70 v / v in $\mathrm{mL}$ ) with the passion juice control. Thus, attributes such as color, flavor (taste) and overall acceptance appear identical. On the other hand, with regard to attributes such as odor and decantation, the passion juice control (T passion) obtained the best scores with respectively 7.33 and 6.52.

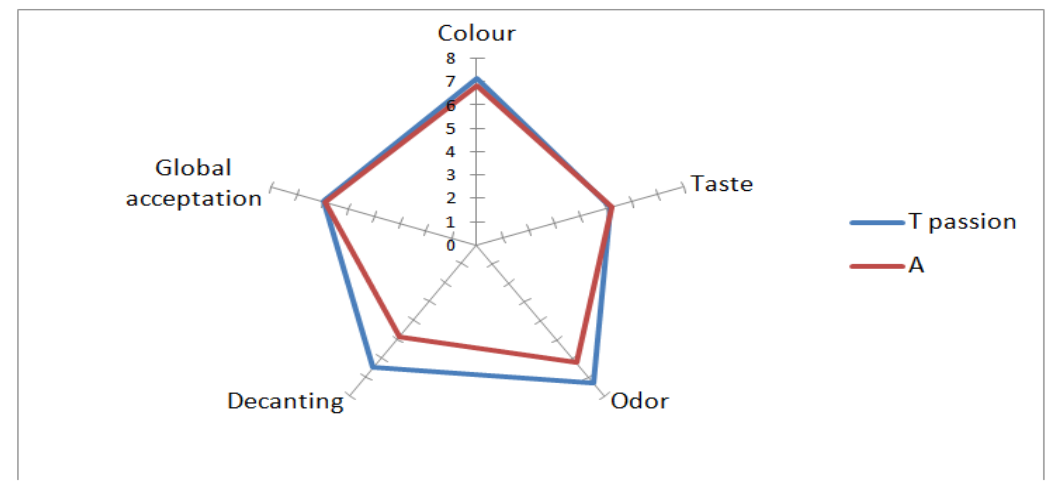

Figure 2: Comparison of blend attributes (A) cashew apple juice-passion fruit juice (30-70 v/v in $\mathrm{mL})$ with the passion juice control

Figure 3 gives the results of the comparison of the attributes of mixture B (mixture of cashew apple juice and passion juice 20-80 v/v in $\mathrm{mL}$ ) with the passion juice control. Thus, attributes such as color, flavor (taste) and overall acceptance compare favorably between mixture B and the control ( $\mathrm{T}$ passion). On the other hand, with regard to attributes such as odor and decantation, the passion juice control obtained the best scores with respect to the mixture $\mathrm{B}$.

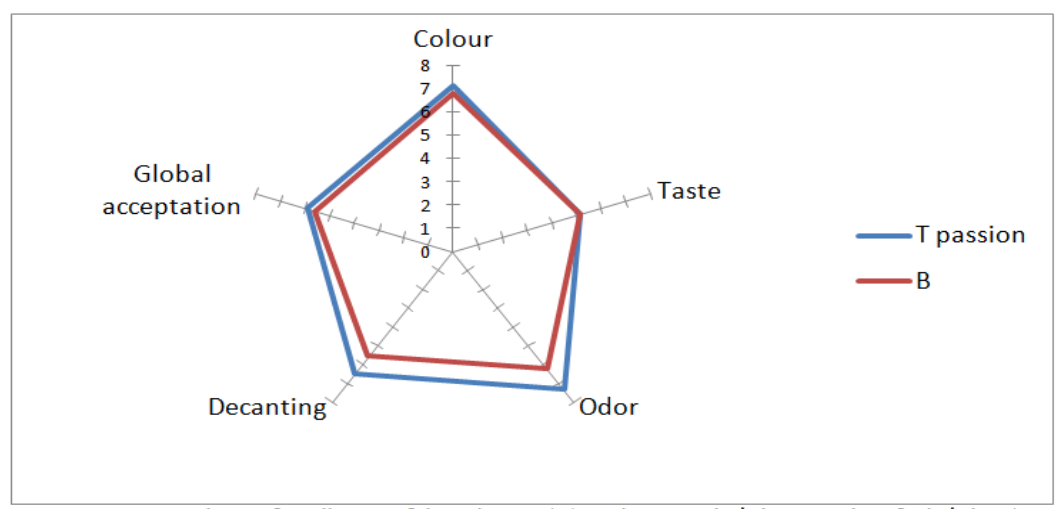

Figure 3: Comparison of attributes of the mixture (B) cashew apple juice-passion fruit juice $(20-80 \mathrm{v} / \mathrm{v}$ in $\mathrm{mL})$ with the passion juice control

Figure 4 gives the results of the comparison of the attributes of the mixture $\mathrm{C}$ (mixture of cashew apple juice and passion juice 10-90 v/v in $\mathrm{mL}$ ) with the passion juice control. Attributes such as color, flavor (taste), decantation and overall acceptance are identical. On the other hand, for the smell the witness of passion juice obtains the best score compared to the mixture $\mathrm{C}$. 


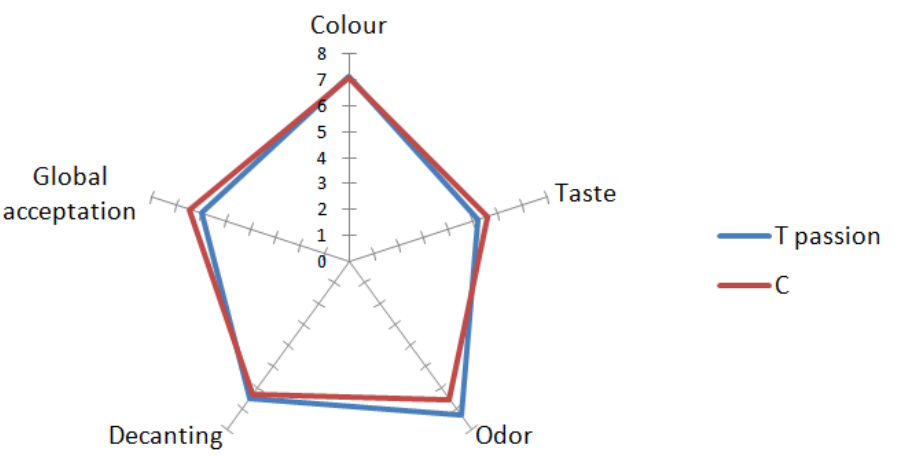

Figure 4: Comparison of attributes of the mixture (C) cashew apple juice-passion fruit juice $(10-90 \mathrm{v} / \mathrm{v}$ in $\mathrm{mL})$ with the passion juice control

IV. CONCLUSION

Mixtures with a variable proportion of passion fruit juice and cashew juice have improved the attributes of the resulting juices. Thus, with regard to the scores the juice of mixture $\mathrm{C}$ seems well appreciated by the panelists. The association of passion juice with cashew juice is therefore a good alternative for the valorization of cashew apple.

\section{REFERENCES}

[1] T.O. Akinwale, "Cashew apple juice: its use in fortifying the nutritional quality of some tropical fruits," European Food Research and Technology, 211, 2000, 205-207.

[2] S.H. Azam-Ali and E.C. Judge, Small-Scale Cashew Nut Processing. ITDG Schumacher Center for Technology and Development Bourton on Dunsmore, Rugby, Warwickhire, UK, 2001, 110p.

[3] J.O. Lawal, O.O. Oduwolé, T.R. Shittu and A.A. Muyiwa, Profitability of value addition to cashew farming households in Nigeria, African Crop Science Journal, 1, 2011, 49-54.

[4] M. Adou, F.A. Tetchi, M. Gbané, K.N Kouassi and N.G. Amani. Physico-chemical characterization of cashew apple juice (Anacardiumoccidentale, L.) from yamoussoukro (Côte d'Ivoire), Innovative Romanian Food Biotechnology, 11, 2012, 32 - 43.

[5] M. Adou, D. A. Kouassi, F. A. Tetchi and N. G. Amani,. Phenolic profile of cashew apple juice (Anacardiumoccidentale L.) from Yamoussoukro and Korhogo (Côte d'Ivoire), Journal of Applied Biosciences, 49, 2012, 3331- 3338.

[6] M. Adou, F.A. Tetchi, J.A. Kouadio and N.G. Amani, Preliminary study of in vivo toxicity of mixture "cashew apple juice-milk" on mice, International Journal of Pharmacy and Pharmaceutical Science Research, 3, 2013, 41-47.

[7] IRD, Les bases de la filière cajou. Projet d'amélioration de la chaine valeur du cajou dans le bassin du fleuve Gambie (CEP). International Relief Development, 2011, 28 p.

[8] Anonyme 1, Côte d'Ivoire : forte poussée de la récolte de cajou en 2015. Jeune Afrique du mois de Juillet 2015.

[9] P.P. Joy, Passion fruit (Passifloraedulis Sims): Passifloraceae. Pineapple Research Station (Kerala Agricultural University), Vazhakulam-686 670, Muvattupuzha District, Kerala, India. 2010, pp 1-8.

[10] AOAC, Official Methods of Analysis, $16^{\text {th }}$ ed., (Association of Official Analytical Chemists, Arlington, 1995, VA).

[11] V.M. Kimaryo, G.A. Massawi, N.A. Olasupo and W.H. Holzapfel, The use of a stater culture in the fermentation of cassava for the production of "Kivunde", a traditional Tanzanian food product, International Journal of Food Microbiology, 56, 2000, 179-190.

[12] Y. Soyer, N. Koca and F. Karadeniz, Organic acid profile of Turkish white grapes and grapes juices, Journal of Food Composition and Analysis, 16, 2003, 629-636.

[13] BIPEA, Recueil des méthodes d'analyse des communautés européennes (Bureau

[14] Interprofessionnel d'Etudes Analytiques, Gennevilliers, France, 1976, 140p).

[15] H. Stone and J.L. Sidel, The roles of sensory evaluation in the food industry, Food Quality and Preference, 23, 1992, 65-73.

[16] U. Talasila, R.R. Vechalapua and B.S. Khasim, Preservation and shelf life extension of cashew apple juice, Internet Journal of Food Safety, 13, 2011, 275-280 